\title{
The Impact of Separation of Control and Cash Flow Rights on Diversification-Evidence from China
}

\author{
SHANG Chun-ling \\ School of Management, Harbin Institute of Technology Shenzhen Graduate School, P.R.China, 518055 \\ GAO Jie (corresponding author) \\ School of Management, Harbin Institute of Technology Shenzhen Graduate School, P.R.China, 518055 \\ E-mail:nerisaaa1@gmail.com \\ ZHANG Hua \\ School of Economics and Management, Harbin Institute of Technology at Weihai, P.R.China, 264209
}

Received: 01-08- 2013

doi:10.7575/aiac.ijfas.v.1n.2p.9
Accepted: 10-09- 2013

Published: 30-10- 2013

URL: http://dx.doi.org/10.7575/aiac.ijfas.v.1n.2p.9

\begin{abstract}
Business diversification could be a channel through which controlling shareholders encroach on the interests of listed companies. Using China's private listed companies of SME (small and medium-sized enterprises) board from 2009 to 2011 as sample, this study investigates the effects of large shareholders' controlling power on the diversification of both listed companies and their holding groups. Our findings demonstrate that the level of listed companies' diversification is positively related to the degree of separation of control rights and cash flow rights of controlling shareholders. Moreover, the higher the separation degree of control and cash flow rights, the higher the level of diversification of the holding groups, indicating diversification is also adopted by the holding group as a channel to expropriate listed companies.
\end{abstract}

Keywords: control rights, cash flow rights, diversification, separation

\section{Introduction}

\subsection{Research background and significance}

Studies have shown that diversification may reduce firm's value, namely "diversification discount". Based on the viewpoint of widely decentralized ownership structure raised by Berle \& Means (1932), business diversification was once believed to be induced by the agency problem between shareholders and managers. Since Shleifer \& Vishny (1997) raised the view that ownership structure was concentrated, some researchers pointed out that large shareholders could use their controlling status to acquire private benefits of control by tunneling (e.g. Johnson et al., 2000). Recent studies show that one of the driving factors of business diversification is the conflict of interests between controlling shareholders and minority shareholders (e.g., Lins and Servaes, 2002).

Similar to most emerging countries, the phenomenon of large shareholder control widely exists in listed companies in China, which stems from China's unique institutional background. In order to meet listing requirements by China Securities Regulatory Commission (CSRC), original parent enterprises established new companies with assets of high quality (e.g. core-business with competitive advantage in technology and high profitability) and got them listed in the stock market. Meanwhile, the non-core business, assets and liabilities with lower profitability were left in the original surviving enterprises to form enterprise group. These enterprise groups become the controlling parent companies of the newly listed companies. In addition, many large shareholders control listed companies through pyramidal structure, leading to the separation of their control rights (i.e., voting rights) and cash flows rights. This separation enables controlling shareholders to enjoy most of the benefits from corporate expansion decisions through high control rights while taking little risk from the potential loss due to low cash flow rights. Furthermore, due to the dual structure of listed companies whose controlling shareholders are state-owned enterprises, the shares owned by large shareholder can't be circulated in China, leading to high illiquid cost to controlling rights. Although China launched the equity division reform aiming at full circulation in 2005, the process haven't completed yet. Thus, the relative high illiquidity of controlling power, together with separation of control and cash flow rights provide the large shareholders with both the incentive and ability to encroach on minority shareholders.

Researchers in China mainly investigate the expropriation behavior of large shareholders from the perspective of cash dividend payments, capital taking up and related party transactions, but rarely from the perspective of diversification (Zhou and Liu, 2004; Rao et al., 2004). Actually, diversification provides a convenient channel for the above activities to be implemented between listed companies and their holding groups. While many studies just analyze the relationship between largest shareholder's ownership and diversification, few studies have traced back to the ultimate controlling shareholders, neither did they find out the primary cause that controlling shareholders acquire private benefits of control 
Furthermore, most listed companies belong to enterprise groups in China and the business of listed companies is related with companies controlled by the same large shareholders. Large shareholders are also likely to transfer the interests of listed companies to achieve the maximization of self-interests through business diversification of the enterprise groups. The advantages and disadvantages of collectivized operation mode have been the topic of hot debate in academic world (e.g., Khanna and Palepu, 2000). Xiao and Kun (2006) find that in countries with weak legal system and corporate governance mechanism, controlling shareholders often taken advantage of the enterprise group to obtain private benefits through related transactions among member enterprises, so that to transfer funds and manipulate profit. Based on a case study, $\mathrm{Mu}$ (2009) discovered that controlling groups encroached on listed companies through group diversification, and listed companies were used as cash machines. However, it is difficult to generalize the conclusion just based on case study, more comprehensive theoretical analysis and empirical evidences are still needed.

From the above analysis, the effect of large shareholder control on diversification deserves further study. Based on research about diversification discount, this article investigates the impact of large shareholder control on the diversified operation of listed companies and their holding groups. This study enriches the literature in large shareholder control and diversification, and explores a new direction for theoretical and empirical studies on company's financial behavior.

\subsection{Theoretical analysis and hypotheses development}

In China's stock market, many large shareholders of listed companies gain the controlling rights in the form of pyramidal holding structure. Under stock pyramids, the ultimate controllers can gain enough rights to completely control the listed companies through control chain. For the controlling shareholders, their cash flow rights are far less than the control rights, resulting in the separation of control and cash flow rights. Zhang et. al. (2007) find that the separation of control and cash flow rights is the primary reason that conflict between large shareholders and minority shareholders exists. Tunneling behavior is based on two conditions. One is that controlling shareholders have relatively concentrated control rights and the other is that the separation of control and cash flow rights exists. The smaller cash flow rights provides large shareholders with the incentive to acquire private benefits of control, while larger control rights enable large shareholders to make operational and financial decisions that are beneficial to their own interests. Thus the separation provides large shareholders with both the motivation and capacity to obtain private benefits of control by encroaching on the interests of minority shareholders.

The pyramidal holding structure provides large shareholders with different ways to encroach on minority shareholders' interests. Diversification is one of them. On one hand, diversification could help large shareholders grab private benefits of control by expanding the scale of investment. On the other hand, diversified operations provide the mask for the interests of listed companies to be transferred to large shareholders through related transactions, funds guarantee or associated capital taking up. In the mean time, unrelated diversification generally leads to higher risk for the listed companies. For example, it may result in excessive investment, shortage of funds and insufficient integration due to blind pursuit of scale expansion, which eventually dilutes the core competitiveness of enterprises. This is the wellknown "diversification discount". The risk of diversification are mainly borne by listed companies while controlling shareholders just bear the corresponding risks associated with their lower cash flow rights. In this way, large shareholders can gain more benefits than loss that "diversification discount" may bring through listed companies' diversification. The higher the degree of separation, the stronger the motive to tunnel, which in turn requires a higher degree of diversification in listed companies. To sum up, we posit the first research hypothesis:

H1: The level of diversification of listed companies is positively related to the separation of control and cash flow rights of controlling shareholders.

China's unique institutional background results in high level of ownership concentration. Most listed companies belong to enterprise groups and their business is related with other companies controlled by the same controlling shareholders. Large shareholders are more likely to transfer the interests of listed companies to achieve the maximization of their own interests through business diversification on group level. Jian (2003), Bozec and Laurin (2008) find that tunneling behavior are more likely to happen in listed companies controlled by groups. To support diversified operation of the business group, lots of working capital is needed and listed companies could be used as cash machines through related transaction to transfer benefits to the group and its subsidiaries. In this way, the controlling group achieves tunneling through diversification in the group level.

Here we take Midea, a leading consumer appliances and air conditioning systems manufacturer in China as an example. Before the split-share reform in 2005, the controlling shareholders' interests and the interests of listed companies were not completely consistent, and the degree of separation of control and cash flow rights was high. In order to maximize controlling shareholders' interests, the listed company mainly played a role of financing platform for the group. The actual controllers obtained private benefits through related transactions between listed companies and other companies controlled by the same controller. Meanwhile, Midea group carried out the strategy of diversification expansion, which weakened the listed company's status. After the split-share reform, the degree of separation of control and cash flow rights decreases, and the controlling shareholders' interests and the interests of the listed company became highly consistent. Thus the controlling shareholders have greater incentive to maximize the economic value of the listed company. The listed company then became a major industrial and capital platform for the group. In the mean time, the group reduces diversification expansion and the performance of listed companies is improved.

When the separation of control and cash flow rights of holding groups exists, the interests of holding groups and listed 
companies are not consistent. In order to maximize their own interests, the controlling groups not only require diversification of listed companies in the firm level, but can also choose diversified operations in group level when listed companies usually play the role of financing platform for the group. As the separation degree decreases, the interests of holding groups and listed companies tend to be more consistent, and the controlling group has greater incentive to increase economic value of the listed company by reducing diversification expansion of the holding group. Therefore, we posit the second research hypothesis:

H2: The level of diversification of the holding group is also positively related to the separation of control and cash flow rights.

\section{Research Method}

\subsection{Variable selection and definition}

\subsubsection{Degree of diversification}

According to extant empirical studies of diversification, this paper adopts two methods to measure the degree of diversification: number of business unit and Herfindahl index. The degree of diversification of listed companies is measured by modified Herfindahl index $(\mathrm{H})$ and number of industries covered by the operation of the company $(\mathrm{N})$, while the degree of group diversification (D) is measured by summing up the number of business units of member companies of the group.

Herfindahl index of revenue is the sum of the square of the proportion of individual business income to total operating revenue. The formula is $H 1=\sum_{i=1}^{N} P i^{2}, i=1,2, \ldots N$, Pi is the proportion for a certain industry that corresponding business income accounts for total revenue, and $\mathrm{N}$ is the number of industries that covers. When the listed company's business scope mainly concentrates in one type of industry, $\mathrm{H}$-value is 1 , which means the enterprise has simplified or specialized business. $\mathrm{H}$ values are in the range of $(0,1]$, and the smaller $\mathrm{H}$ is, the higher the degree of diversification. To transform $\mathrm{H}$ into an indicator that is positively related to the degree of diversification, we make the following transformation: $H=1-\sum_{i=1}^{N} P i^{2}, i=1,2, \ldots N$. So that the $\mathrm{H}$ values lie in in the range of $[0,1)$, and the greater $\mathrm{H}$ is, the higher the degree of diversification. $\mathrm{H}$ varies with the degree of diversification of listed companies in the same direction. We use $\mathrm{H}$ to measure the degree of diversification of listed companies.

Number of business unit $(\mathrm{N})$ is the number of industries that the operations of listed companies cover. This index can intuitively reflect the level of diversification and is simple to calculate, so it is widely used. Most literatures set $10 \%$ as standard, if one type of business revenue accounts for more than $10 \%$ of total operating income, it is called a unit.

As for the degree of holding group's diversification (D), we collect the data from the annual reports of listed companies about the scope of business and information about member companies of the holding group. We also collect other relevant data from the websites of related companies. We sum up the number of business unit $(\mathrm{N})$ of the member companies of the holding group and get the degree of holding group's diversification (D).

\subsubsection{Separation degree of control and cash flow rights}

We use the ratio of control rights to cash flow rights of controlling shareholders to measure the separation degree of control and cash flow rights (SEPAR). This method was proposed by La porta in 1999. Control rights refer to the ultimate voting rights of ultimate controller on the target company, including direct control rights and indirect control rights. Direct control rights are the shares directly held by actual controllers. Indirect control rights are the shares indirectly held, which is equal to the minimum number of shares held by the controller on a single control chain. So control rights are equal to the sum of the minimum of voting rights on each control chain. Cash flow rights are also called ownership, which is the right to share earnings based on the shares of target company held by the controller, also including direct and indirect cash flow rights. Direct cash flow rights are the rights to share earnings based on the shares directly held. Indirect cash flow rights are the product of shareholding of each level on eachcontrol chain. We get the ultimate cash flow rights by summarizing the cash flow rights of each control chain.

The specific calculation process is as follows:

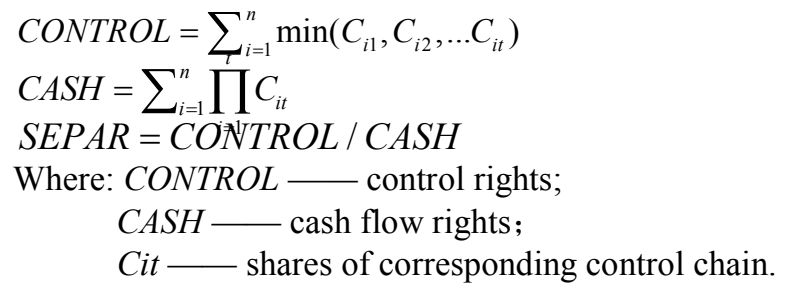

SEPAR refers to the separation degree of control and cash flow rights. It indicates that the separation of control and cash flow rights does not exist when SEPAR is equal to 1. Only when SEPAR is greater than 1, the separation of control rights and cash flow rights exists. The greater the SEPAR value, the higher the degree of separation.

In order to better illustrate the calculation method of control and cash flow rights, we take the equity structure of a listed company Welltech (Stock Code. 002058) as an example. The control diagram of Welltech is as follows: 


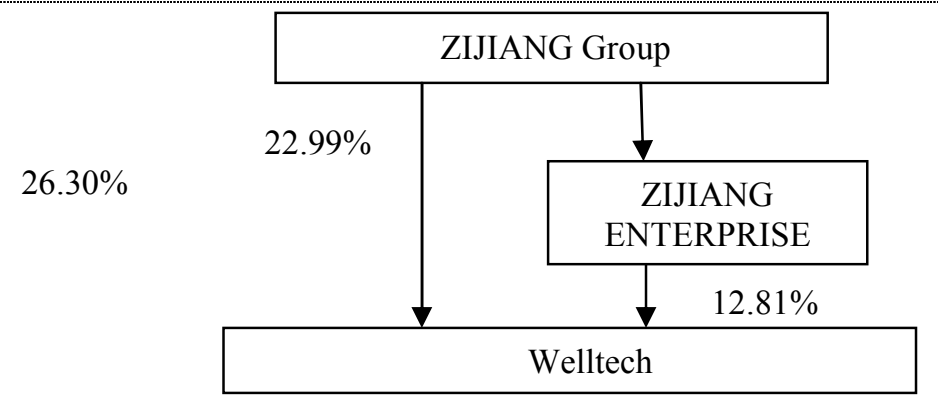

Figure1. The property and control diagram of Welltech

As the above diagram shows, the ultimate controller of Welltech is ZIJIANG Group. The direct control right is $26.3 \%$ (left hand side), the indirect control right is realized through controlling ZIJIANG ENTERPRISE (right hand side). The level of indirect control right is $\min (22.99 \%, 12.81 \%)=12.81 \%$, which means the voting rights ZIJIANG Group gains over Welltech through this chain of control is $12.81 \%$. Thus the total control right is $26.3 \%+12.81 \%=39.11 \%$. On the other hand, the direct cash flow right of ZIJIANG Group over Welltech is $26.3 \%$ (left hand side), while the indirect cash flow right, which is the right to share the residual income of Welltch (right hand side), is obtained by taking the product of the cash flows rights over the chain: $22.99 \% \times 12.81 \%=2.945 \%$. Thus the total cash flow right is $26.3 \%+$ $2.945 \%=29.245 \%$. The degree of separation of control and cash flow right is thus $39.53 \% / 29.245 \%=1.3373$. This value is larger than 1 , indicating the existence of the separation of control and cash flow right. The above diagram illustrates clearly that the separation of rights derives from pyramid holding structure.

\subsubsection{Control variables}

According to previous literature (Chen and Ho 2000, Denis et. al. 1997, Wang and Hu 2005), the operating performance of previous year, company size, financial leverage, time of establishment, ability to grow may affect the level of diversification, thus we use the above five factors as control variables.

Table 1. Variable definitions and estimation methods

\begin{tabular}{|c|c|c|c|}
\hline Types & Variables & $\begin{array}{l}\text { Variable } \\
\text { symbol }\end{array}$ & Variable definitions \\
\hline \multirow{3}{*}{$\begin{array}{l}\text { Dependent } \\
\text { variables }\end{array}$} & $\begin{array}{c}\text { Modified } \\
\text { Herfindahl index }\end{array}$ & $\mathrm{H}$ & $\begin{array}{l}\qquad H=1-\sum_{i=1}^{N} P i^{2}, i=1,2, \ldots N \text {. } \\
\mathrm{Pi} \text { is the proportion for a certain industry business } \\
\text { income accounted for total revenue, and } \mathrm{N} \text { is the number } \\
\text { of industries that covers. }\end{array}$ \\
\hline & $\begin{array}{l}\text { Number of } \\
\text { business unit }\end{array}$ & $\mathrm{N}$ & Number of industries that the operating income covers \\
\hline & $\begin{array}{c}\text { Diversification } \\
\text { degree of holding group }\end{array}$ & $\mathrm{D}$ & Number of industries all subsidiaries cover \\
\hline $\begin{array}{l}\text { Independent } \\
\text { variables }\end{array}$ & $\begin{array}{l}\text { Separation degree of } \\
\text { control and cash flow } \\
\text { rights }\end{array}$ & $\begin{array}{l}\text { SEPA } \\
\mathrm{R}\end{array}$ & Ratio of control rights to cash flow rights \\
\hline \multirow{5}{*}{$\begin{array}{c}\text { Control } \\
\text { variables }\end{array}$} & $\begin{array}{c}\text { Last year's } \\
\text { operating performance }\end{array}$ & PERF & Last year's EBIT / operation revenue \\
\hline & Company size & SIZE & Natural logarithm of year-end total assets \\
\hline & $\begin{array}{c}\text { Age of } \\
\text { Establishment }\end{array}$ & AGE & Natural logarithm of established age \\
\hline & Financial leverage & LEV & Year-end total liabilities/year-end total assets \\
\hline & Ability to grow & GROWTH & Growth rate of net profit of previous year \\
\hline
\end{tabular}

\subsection{Sampling Procedures}

This study selects private-owned listed companies from small and medium-sized board in Chinese stock market from 2009 to 2011 as sample, and traces the actual controlling shareholders based on the annual report of listed companies. The reason we use private-owned listed companies as sample is that in China, most of private-owned companies adopt the pyramid shareholding structure, resulting in greater degree of separation of control and cash flow right. This kind of governance structure makes it easier for us to investigate the diversified operations. On the other hand, the ultimate controller of state-owned enterprises is the government, which could bring in other incentives that influence diversified 
business behavior. The sample period starts from 2009 to avoid the potential impact of financial crisis on the business diversification of companies in 2008. Specifically, we select the listed companies whose controlling shareholders are groups, then we eliminate the companies with incomplete information of control chain and prime operating revenue, eventually we get 168 companies. All the financial data comes from resset financial database (www.resset.cn) and cninfo(www.cninfo.com.cn). Data about control rights and cash flow rights are obtained from the annual report of each listed company. We refer to companies' website to get data about the degree of diversification of holding groups.

We first describe the main variables used in empirical tests, then we illustrate the empirical models.

\subsection{Research design}

To test the hypotheses developed in section 2, we build two empirical models as follows:

\section{Model 1:}

$$
H=\alpha_{0}+\alpha_{1} \times S E P A R_{i}+\alpha_{2} \times S I Z E_{i}+\alpha_{3} \times L E V_{i}+\alpha_{4} \times A G E_{i}+\alpha_{5} \times P E R F_{i}+\alpha_{6} \times G R O W T H_{i}+\varepsilon
$$

Model 1 investigates the effect of separation of control rights and cash flow rights of controlling shareholders on the diversification level of listed companies. According to $\mathrm{H} 1$, we predict that the coefficient on $S E P A R_{i}, \alpha_{1}$ to be positive.

\section{Model 2:}

$$
D=\beta_{0}+\beta_{1} \times S E P A R_{i}+\beta_{2} \times S I Z E_{i}+\beta_{3} \times L E V_{i}+\beta_{4} \times A G E_{i}+\beta_{5} \times P E R F_{i}+\beta_{6} \times G R O W T H_{i}+\varepsilon
$$

Model 2 investigates the effect of separation of control rights and cash flow rights of controlling shareholders on the diversification level of the holding groups of listed companies. According to $\mathrm{H} 2$, we predict that the coefficient on $S E P A R_{i}, \beta_{1}$ to be positive. The variables in the two regression models are described in table 1.

\section{Empirical Results}

\subsection{Descriptive statistics}

Table 2 summarizes the main variables of interest. In the sample of 168 private-owned listed companies of SME board, the average of listed companies' modified Herfindahl index is 0.109 , the maximum is 0.729 , and the minimum is 0 , which shows that the overall diversification degree of listed companies is not high. As for the degree of diversification of listed companies measured by business unit number, $\mathrm{N}$, the mean value is 1.27 , the maximum is 3 , meanings that the maximum number of industry the firm's operation covers is 3 . The mean value of controlling groups' degree of diversification is 4.62 , the maximum is 11 , which means on average, the operations of holding group cover 4.6 industries. Regarding the separation degree of control and cash flow rights, the mean value is 1.58 , the maximum is 3.71 , with the minimum value of 1 , showing that on average, for listed companies with business group as controlling shareholders, the level of voting rights is about $50 \%$ higher than cash flow rights.

Table 2. Descriptive statistics of main variables

\begin{tabular}{lcccccc}
\hline Variables & Obs & Min & Max & Mean & Median & Std. dev \\
\hline $\mathrm{H}$ & 168 & 0.000 & 0.729 & 0.109 & 0.000 & 0.178 \\
$\mathrm{~N}$ & 168 & 1.000 & 3.000 & 1.270 & 1.000 & 0.507 \\
$\mathrm{D}$ & 168 & 1.000 & 11.000 & 4.620 & 4.000 & 2.215 \\
SEPAR & 168 & 1.000 & 3.710 & 1.580 & 1.440 & 0.611 \\
PERF & 168 & -113.204 & 55.238 & 11.348 & 9.851 & 14.794 \\
GROWTH & 168 & -21.230 & 22.424 & 0.462 & 0.166 & 2.803 \\
LEV & 168 & 0.057 & 0.798 & 0.405 & 0.390 & 0.189 \\
AGE & 168 & 1.072 & 3.150 & 2.240 & 2.223 & 0.398 \\
SIZE & 168 & 19.207 & 22.741 & 21.087 & 21.129 & 0.752 \\
\hline
\end{tabular}

Table 3 presents Pearson correlations results between variables. Not surprisingly, the modified Herfindahl index and business unit number of listed companies are positively correlated (0.798) and highly significant. Moreover, the modified Herfindahl index and SEPAR are positively related (0.411), suggesting that higher degree of separation between cash flow rights and control rights is associated with more diversified business of listed companies. Further, diversification level of the holding group (D) and SEPAR are also positively related (0.053), indicating that higher separation level between cash flow rights and control rights is associated with higher degree of diversification in group level. 
Table 3. Pearson correlation analysis

\begin{tabular}{cccccccccc}
\hline Variables & $\mathrm{H}$ & $\mathrm{N}$ & $\mathrm{D}$ & SEPAR & PERF & GROWTH & LEV & AGE & SIZE \\
\hline $\mathrm{H}$ & 1 & & & & & & & & \\
$\mathrm{~N}$ & $0.798^{* * *}$ & 1 & & & & & & & \\
$\mathrm{D}$ & 0.077 & 0.075 & 1 & & & & & & \\
SEPAR & $0.411^{* * *}$ & $0.341^{* * *}$ & $0.053^{* *}$ & 1 & & & & & \\
PERF & -0.065 & -0.020 & -0.019 & 0.020 & 1 & & & & \\
GROWTH & 0.006 & 0.017 & $0.175^{* *}$ & 0.084 & -0.078 & 1 & & \\
LEV & 0.020 & 0.044 & 0.086 & -0.064 & $-.287^{* * *}$ & -0.048 & 1 & \\
AGE & -0.018 & -0.063 & 0.015 & $0.310^{* * *}$ & 0.008 & -0.029 & -0.086 & 1 & \\
SIZE & -0.118 & -0.043 & 0.010 & $-0.221^{* * *}$ & $0.180^{* *}$ & 0.014 & $0.320^{* * *}$ & 0.056 & 1 \\
\hline
\end{tabular}

The sample includes 168 firm observation from 2009 to 2011 . H represents the modified Herfindahl index which measures the level of diversification of listed companies. $\mathrm{N}$ is the number of industries the operating income of listed companies covers. $\mathrm{D}$ is the number of industries all subsidiaries of the controlling group cover. It is used to measure the diversification level of the controlling group. SEPAR is the ratio of controlling shareholder's voting rights to cash flow rights, showing the separation degree of the two rights. PERF represents the operating performance of previous year as defined by the ratio of EBIT to operation revenue. GROWTH is previous year growth rate of net profit. LEV is the ratio of yearend liabilities to total assets. AGE and SIZE are the natural logarithm of the age and total assets of listed companies respectively. $*, * *, * * *$ denote $10 \%, 5 \%, 1 \%$ significance level respectively.

\subsection{Regression analysis}

Table 4 presents the multivariate regression results for model 1. We use Modified Herfindahl index (H) and Number of business unit $(\mathrm{N})$ to measure the degree of diversification of listed companies. We could see from table 4 that when Modified Herfindahl index $(\mathrm{H})$ is used as dependent variable, the coefficient on the separation degree of control and cash flow rights (SEPAR) is positive (0.468) and significant at $1 \%$ level. When number of business unit (N) is used to represent the degree of diversification in listed companies, the coefficient of SEPAR is also positive (0.419) and significant at the level of $1 \%$. The results indicate that the greater the degree of separation, the higher the level of diversification of listed companies. H1 is also supported.

Table 4. Relation between diversification of listed companies and separation degree

\begin{tabular}{ccc}
\hline & $\mathrm{H}$ & $\mathrm{N}$ \\
\hline SEPAR & $0.468^{* * * *}$ & $0.419^{* * *}$ \\
PERF & $(0.000)$ & $(0.000)$ \\
& -0.075 & -0.033 \\
GROWTH & $(0.338)$ & $(0.686)$ \\
& -0.043 & -0.026 \\
LEV & $(0.548)$ & $(0.724)$ \\
AGE & 0.010 & 0.025 \\
& $(0.903)$ & $(0.768)$ \\
SIZE & $-0.163^{* *}$ & $-0.194^{* *}$ \\
& $(0.033)$ & $(0.014)$ \\
Obs & 0.006 & 0.059 \\
Adj. $\mathrm{R}^{2}$ & $(0.939)$ & $(0.485)$ \\
\hline
\end{tabular}

This table provides empirical results for Model 1. Dependent variables are $\mathrm{H}$ and $\mathrm{N}$ respectively, which denote the diversification level of listed companies. H represents the modified Herfindahl index. $\mathrm{N}$ is the number of industries the operating income of listed companies covers. SEPAR is the ratio of controlling shareholder's voting rights to cash flow rights, showing the separation degree of the two rights. PERF represents the operating performance of previous year as defined by the ratio of EBIT to operation revenue. GROWTH is previous year growth rate of net profit. LEV is the ratio of yearend liabilities to total assets. AGE and SIZE are the natural logarithm of the age and total assets of listed companies respectively. $* * *$ and $* * *$ denote significance at $10 \%, 5 \%, 1 \%$ levels respectively.

Table 5 presents the multivariate regression results for model 2. We could observe from table 5 that the separation degree of control and cash flow rights has a significant positive influence on the degree of diversification of controlling group, and the coefficient of SEPAR is 0.031 , significant at the level of $5 \%$, which shows that the greater the degree of separation, the higher the level of diversification of the controlling groups. $\mathrm{H} 2$ is also supported. 
Table 5. Relation between diversification of controlling group and separation degree

\begin{tabular}{|c|c|}
\hline & $\mathrm{D}$ \\
\hline \multirow{2}{*}{ SEPAR } & $0.031^{* *}$ \\
\hline & $(0.043)$ \\
\hline \multirow{2}{*}{ PERF } & 0.034 \\
\hline & $(0.694)$ \\
\hline \multirow{2}{*}{ GROWTH } & $0.182^{* *}$ \\
\hline & $(0.022)$ \\
\hline \multirow{2}{*}{ LEV } & 0.118 \\
\hline & $(0.186)$ \\
\hline \multirow{2}{*}{ AGE } & 0.022 \\
\hline & $(0.793)$ \\
\hline \multirow{2}{*}{ SIZE } & -0.031 \\
\hline & $(0.732)$ \\
\hline Obs & 168 \\
\hline Adj. $\mathrm{R}^{2}$ & 0.110 \\
\hline
\end{tabular}

This table provides empirical results for Model 2. Dependent variable is D, which is the number of industries all subsidiaries of the controlling group cover. It stands for the diversification level of the controlling group. SEPAR is the ratio of controlling shareholder's voting rights to cash flow rights, showing the separation degree of the two rights. PERF represents the operating performance of previous year as defined by the ratio of EBIT to operation revenue. GROWTH is previous year growth rate of net profit. LEV is the ratio of yearend liabilities to total assets. AGE and SIZE are the natural logarithm of the age and total assets of listed companies respectively. $* * *$ and $* * *$ denote significance at $10 \%, 5 \%, 1 \%$ levels respectively.

\section{Discussion}

In this study, we investigate the impact of separation of control and cash flow rights of controlling shareholders on the diversification of listed companies and holding groups for privately-owned listed companies in China. We find that the degree of separation between control and cash flow rights of controlling shareholders is not only positively associated with the diversification level of listed companies, but also positively related with the diversification level of the holding groups.

The contribution of our study is that we propose the separation between control rights and cash flow rights as an important determinant for listed companies (and groups) to diversify their business. While previous studies find the widely existing phenomenon of "diversification discount", our study suggests an explanation for it, i.e., the separation between control rights and cash flow rights provides the incentive for the controlling shareholders to encroach on small shareholders through diversified operations, which is likely to jeopardize value of listed companies. Furthermore, we provide a more complete picture about the diversification activities by examining not only the operations of listed companies, but also those of the holding groups. An extension of this study would be to further investigate the relation between separation of control and cash flow rights on specific business activities that facilitate diversification of listed companies and the holding groups, as well as their effect on firm future performance. It would also be interesting to look at the factors that may restrict the value-reducing diversification activities Examination of such topics appears to be worthwhile for future research.

\section{References}

Bozec, Y. \& Laurin, C. (2008) Large shareholder entrenchment and performance: empirical evidence from Canada. Journal of Business Finance and Accounting, 35(1\&2), 25-49.

Chen, S.S. \& Ho, K.W. (2000) Corporate diversification, ownership structure, and firm value: the Singapore Evidence. International Review of Financial Analysis, 9 (3), 315-326.

Claessens, S., Djankov, S. J., Fan P. H.\& Lang, L.H.P. (1999). Corporate diversification in East Asia: the role of ultimate ownership and group affiliation. Working paper, World Bank.

Denis, D. J., Denis, D. K. \& Sarin, A. (1997). Agency problems, equity ownership, and corporate diversification. Journal of Finance 52(1), 135- 160.

Dun, Y. X. \& Xue, Y. Z. (2007). Actual controllers of listed companies, diversification and investors protection. Securities Market Herald, 9, 67-72.

Han, Z. X. \& Zhu, R. L. (2007). The excess control, board structure and corporate diversification discount. Nankai Business Review, 1, 16-20.

Johnson, S., La Porta, R., Florencio, L-S \& Shleifer, A. (2000). Tunneling. American Economic Review, 90 , 22-27.

Khanna, T. \& Palepu, K. (2000) Is group affiliation profitable in emerging markets: an analysis of diversified Indian business group. Journal of Finance, 55(2), 867-891.

Lins, K.V. \& Servaes, H. (2002). Is corporate diversification beneficial in emerging markets? Financial Management, 31(2), 5-31. 
Liu, F., Wei, M. H.\& He, J. G. (2004). Control rights, performance and tunneling- — a case study based on Wuliangye. Management World, 9, 102-110.

Mu, Y. Q. 2009. Tunneling under enterprise group diversification—a case analysis based on Chunlan. Knowledge Economy, 15, 3-4.

Papke-Shields, K. E. \& Malhotra, M. K. (2001). Assessing the impact of the manufacturing executives role on business performance through strategic alignment. Journal of Operations Management, 19(1), 5-22.

Rao, X., Tang, L., Jiang, Y. \& Liu, B. (2004). An empirical research on the relationship between diversification and equity structure of listed companies in China, Economic Management, 2, 82-88.

Shieifer, A. \& Vishny, R.W. (1997). A survey of corporate governance. Journal of Finance, 52(2), 737-783.

Wang, H. C \& Hu, G. L. (2005). The relationship between ownership structure and corporate diversification: theory and empirical analysis. Accounting Research, 8, 56-62.

Wong, T. J. \& Jian, M. (2003). Earnings management and tunneling through related party transactions: evidence from Chinese corporate groups. EFA 2003 Annual Conference Paper, No. 549.

Xiao, X. \& Wang, K. (2006). An empirical research on group mode diversification - empirical evidence from the faction of listed companies. Management World, 9, 102-118.

Yakov, A. \& Lev, B. (1981). Risk Reduction as a managerial motive for conglomerate mergers. The Bell Journal of Economics 12 (2), 605-617.

Yuan, L. \& Liu, C. (2010). Large shareholder control, private benefit and diversification. West Forun. 1, 87-94.

Zhang, G. G., Zeng, Y. \& Deng, J. P. (2007). Research review on large shareholder governance and agency problems between shareholders. Journal of Management, 4(3), 363-372.

Zhang, Y., Li, X. \& Xu, D. Y. (2005). Agency problems, equity structure and corporate diversification. Economic Science, 3, 90-99.

Zhou, X. Y. \& Liu, M. S. (2004). Review on corporate governance structure from diversification behavior. Modern Management Science. 2, 32- 34. 